\title{
New spectroscopic and electrochemical insights on a class I superoxide reductase: evidence for an intramolecular electron-transfer pathway
}

\author{
Filipe FOLGOSA, Cristina M. CORDAS, Joana A. SANTOS ${ }^{1}$, Alice S. PEREIRA, José J. G. MOURA, Pedro TAVARES ${ }^{2}$ and \\ Isabel MOURA ${ }^{2}$ \\ REQUIMTE/CQFB, Departamento de Química, Faculdade de Ciências e Tecnologia, Universidade Nova de Lisboa, 2829-516 Caparica, Portugal
}

\begin{abstract}
SORs (superoxide reductases) are enzymes involved in bacterial resistance to reactive oxygen species, catalysing the reduction of superoxide anions to hydrogen peroxide. So far three structural classes have been identified. Class I enzymes have two ironcentre-containing domains. Most studies have focused on the catalytic iron site (centre II), yet the role of centre I is poorly understood. The possible roles of this iron site were approached by an integrated study using both classical and fast kinetic measurements, as well as direct electrochemistry. A new heterometallic form of the protein with a zinc-substituted centre I, maintaining the iron active-site centre II, was obtained, resulting in a stable derivative useful for comparison with the native all-iron from. Second-order rate constants for the electron transfer between reduced rubredoxin and the different SOR forms
\end{abstract}

were determined to be $2.8 \times 10^{7} \mathrm{M}^{-1} \cdot \mathrm{s}^{-1}$ and $1.3 \times 10^{6} \mathrm{M}^{-1} \cdot \mathrm{s}^{-1}$ for $\mathrm{SOR}_{\mathrm{Fe}(\mathrm{IIII})-\mathrm{Fe}(\mathrm{II})}$ and for $\mathrm{SOR}_{\mathrm{Fe}(\mathrm{IIII})-\mathrm{Fe}(\mathrm{III})}$ forms respectively, and $3.2 \times 10^{6} \mathrm{M}^{-1} \cdot \mathrm{s}^{-1}$ for the $\mathrm{SOR}_{\mathrm{Zn} \text { (II)-Fe(III) }}$ form. The results obtained seem to indicate that centre I transfers electrons from the putative physiological donor rubredoxin to the catalytic active iron site (intramolecular process). In addition, electrochemical results show that conformational changes are associated with the redox state of centre I, which may enable a faster catalytic response towards superoxide anion. The apparent rate constants calculated for the SOR-mediated electron transfer also support this observation.

Key words: electron transfer, non-mediated electrochemistry, reactive oxygen species (ROS), superoxide reductase.

\section{INTRODUCTION}

Oxygen is one of the most abundant elements in biology. In its ground state, $\mathrm{O}_{2}$ is a triplet, whereas most of its reactants are singlets, leading to spin-forbidden processes. Thus reactions between molecular oxygen and other molecules should be kinetically unfavourable, requiring large activation energies [1]. Over the years, biology has overcome this problem by using transition metals, such as iron, for pairing electrons in a process called 'oxygen activation' [2-5]. This complementarity enables oxygen to participate in biological cycles, but can also lead to the formation of ROS (reactive oxygen species). Owing to this behaviour, a large protection mechanism is required in order to overcome the possible lethal effects of the reactive species formed in the cell.

Since the early 1990s, several reports of new classes of non-haem iron protein isolation and characterization have been published [6-16]. However, only in 1999 was the real function of some of these proteins assigned [17]. The so-called SORs (superoxide reductases) revealed a new way to reduce, by one electron, the superoxide anion to hydrogen peroxide (eqn 1), instead of the well-known reaction of dismutation (eqn 2), performed by SODs (superoxide dismutases) [17,18].

$\mathrm{O}^{-}{ }_{2}+2 \mathrm{H}^{+}+\mathrm{e}^{-} \rightarrow \mathrm{H}_{2} \mathrm{O}_{2}(\mathrm{SOR})$

$2 \mathrm{O}^{-}{ }_{2}+2 \mathrm{H}^{+} \rightarrow \mathrm{O}_{2}+\mathrm{H}_{2} \mathrm{O}_{2}(\mathrm{SOD})$

This capability has enormous biological relevance if we consider that the majority of these SOR proteins were first purified from anaerobes, giving them the skills to survive in small amounts of both oxygen and its reaction products $[7,9,10]$.

SORs are usually divided into three classes, according to the number of iron centres (two irons per protein monomer for class I and one iron per monomer for class II and III SORs) and primary structure (the presence of an extra N-terminal domain) [19]. Centre I contains an iron atom co-ordinated by four cysteine residues $\left\{\left[\mathrm{Fe}(\mathrm{S}-\mathrm{Cys})_{4}\right]\right\}$ in a way similar to the one identified in desulforedoxin [20,21], whereas centre II has an iron atom coordinated by four histidine residues in the equatorial plane and one cysteine residue in the axial plane $\left\{\left[\mathrm{Fe}(\mathrm{S}-\mathrm{Cys})(\mathrm{N}-\mathrm{His})_{4}\right]\right\}$ $[9,10,19,22]$.

Class I SORs were first isolated by Moura et al. [10] from the sulfate- and nitrate-reducing bacteria Desulfovibrio desulfuricans A.T.C.C. 27774 [10]. This dimeric protein (two monomers of $14 \mathrm{kDa}$ each) can have three different oxidation states, fully reduced (both centres in the reduced form), half-reduced (centre I in the oxidized form and centre II in the reduced form) and fully oxidized (both centres in the oxidized form). The UV-visible spectrum of the half-reduced form is dominated by maxima at 495,368 and $279 \mathrm{~nm}$, whereas in the fully oxidized form the UVvisible spectrum shows additional bands at 335 and $635 \mathrm{~nm}$. The fully reduced form has no absorption bands in the visible region of the spectrum. The EPR spectrum of the half-reduced form shows a set of resonances $(g=7.7,5.7,4.1$ and 1.8) characteristic of a high-spin ferric ion $(S=5 / 2)$ with an E/D value of 0.08 , whereas the fully oxidized form has additional resonances at $g=4.3$ and 9.6. Mössbauer spectroscopy clearly indicated the presence of two high-spin iron centres, where the component attributed to centre II is characteristic of a high-spin ferric ion with an E/D of approximately one-third $[7,10]$.

Abbreviations used: DP, differential pulse; IPTG, isopropyl $\beta$-D-thiogalactopyranoside; LB, Luria-Bertani; NHE, normal hydrogen electrode; ROS, reactive oxygen species; SOD, superoxide dismutase; SOR, superoxide reductase; SW, square-wave.

Present address: Instituto de Biologia Molecular e Celular, Rua do Campo Alegre, 823, 4150-180 Porto, Portugal

2 Correspondence may be addressed to either of these authors (email pedro.tavares@dq.fct.unl.pt or isa@dq.fct.unl.pt). 
The class II SOR was first isolated and described by Chen et al. [9] in 1994, from the sulfate-reducing bacterium Desulfovibrio gigas. In a similar manner to class I SORs, this is also a dimeric protein with $14 \mathrm{kDa}$ per monomer; however, in this case, these proteins only have one iron per monomer, similar to centre II of class I SORs $\left\{\left[\mathrm{Fe}(\mathrm{S}-\mathrm{Cys})(\mathrm{N}-\mathrm{His})_{4}\right]\right\}$. Also, the N-terminal domain of this class of proteins does not present the cysteine motif that co-ordinates the iron atom in centre I of class I SORs. The EPR spectrum of the oxidized form $(S=5 / 2)$ of these proteins shows a $\mathrm{pH}$-dependence with $\mathrm{E} / \mathrm{D}$ values of 0.06 for lower $\mathrm{pH}$ values and more rhombic conformations, and $\mathrm{E} / \mathrm{D} \approx 0.33$ for the highest $\mathrm{pH}$ values. The UV-visible spectrum exhibits $\mathrm{pH}$-dependent absorption bands with $\mathrm{pKa} \approx 9.6$ and maxima ranging from 660 and $600 \mathrm{~nm}$, from lowest to highest $\mathrm{pH}$ values $[9,23]$.

An analysis of the Treponema pallidum genome revealed a gene highly homologous with the class I SOR with two domains, named class III SOR. However, in this case, domain I lacked three of the four cysteine residues responsible for the centre I iron-binding site. The gene product expressed in Escherichia coli had a molecular mass of approximately $14 \mathrm{kDa}$ per monomer, and the EPR and Mössbauer features are similar to centre II of the class I SOR. Enzymatic studies revealed that this protein was able to reduce superoxide anion to hydrogen peroxide, and that rubredoxin, isolated from the same organism, is capable of donating electrons to SOR [12,16,24].

Extensive studies on the catalytic mechanism of the three enzyme classes have been reported over the last 10 years, in particular on class I SORs isolated from many bacteria and archaea, such as Desulfovibrio vulgaris strain Hildenborough, D. desulfuricans A.T.C.C. 27774, Desulfoarculus baarsii and Archaeoglobus fulgidus [13,14,25-28].

In 2000, Ascenso et al. [29] published the cloning of two engineered constructs, expressed separately in E. coli. The Nterminal domain (DfxN) consisted of the first 39 amino acids from $D$. vulgaris Hildenborough SOR that resembles $D$. gigas desulforedoxin. The C-terminal domain consisted of the last 92 amino acids of $D$. vulgaris Hildenborough SOR (DfxC). Both recombinant fragments were able to bind iron, despite the fact that, in DfxC, the iron showed a labile behaviour. Biochemical and spectroscopic features of DfxN and DfxC have properties similar to desulforedoxin and centre II of class I SORs respectively. The authors also tested the reaction of DfxC with superoxide, but there was no evidence of reduction. This was related to the possible loss of iron in the catalytic centre [29].

In a different study, Kurtz and co-workers [30] reported a $2 \mathrm{Fe}-\mathrm{SOR}$ mutant, C13S, from D. vulgaris Hildenborough. This protein revealed spectroscopic features similar to those previously described for centre II of class I SORs. This mutant also revealed similar behaviour when reacted with superoxide, indicating that rubredoxin efficiently donates electrons to centre II. However, as in DfxC, the C13S mutant is also less stable than the wild-type form [30].

In the present study we propose to characterize not only the biological relevance of centre I in the class I SORs (as a putative redox centre), but also its role in the enzyme mechanism. The iron atom located at centre I was replaced by a zinc atom, making it unavailable for electron transfer. We demonstrate the differences in catalytic activity of the protein when only one or both centres are present, and also characterize the direct electron-transfer pathways between the SOR and the common accepted physiological electron donor rubredoxin [24,26,31]. Several techniques, such as UV-visible, stopped-flow, EPR and also direct electrochemistry, were used to accomplish the biochemical and spectroscopic characterization.

\section{EXPERIMENTAL}

\section{Chemicals}

Bovine $\mathrm{Cu}, \mathrm{Zn} \mathrm{SOD}$, bovine milk xanthine oxidase, xanthine, horse heart cytochrome $c$, LB (Luria-Bertani) medium, ampicillin, IPTG (isopropyl $\beta$-D-thiogalactopyranoside), DNAse and sodium hexachloroiridate were purchased from SigmaAldrich. All buffers were from Merck. Competent E. coli BL21(DE3) cells were purchased from Stratagene. All of the reagents used were of analytical grade or higher.

\section{Overexpression and purification of recombinant $D$. vulgaris Hildenborough rubredoxin}

D. vulgaris Hildenborough rubredoxin was overexpressed and purified to homogeneity following a modified protocol from one published previously [24,31] (described in the Supplementary Experimental section at http://www.BiochemJ.org/bj/438/ bj4380485add.htm).

\section{Overexpression and purification of recombinant $D$. gigas desulforedoxin}

D. gigas desulforedoxin was overexpressed and purified to homogeneity following a protocol modified from one published previously [20] (described in the Supplementary Experimental section).

\section{Overexpression and purification of recombinant $D$. vulgaris Hildenborough 2Fe-SOR}

Production of recombinant $D$. vulgaris Hildenborough $2 \mathrm{Fe}-\mathrm{SOR}$ followed a protocol modified from one published previously $[29,31]$. In the present study, the cell culture was allowed to grow at $310.15 \mathrm{~K}$ at $230 \mathrm{rev} . / \mathrm{min}$ until its $D$ at $600 \mathrm{~nm}$ was near 0.8 in $\mathrm{M} 9$ medium containing $0.1 \mathrm{mg} / \mathrm{ml}$ ampicillin and $0.1 \mathrm{mM} \mathrm{FeCl}$. At this time, $1 \mathrm{mM}$ IPTG and $0.1 \mathrm{mM} \mathrm{FeCl} 2$ were added and the culture was able to grow for approximately $14 \mathrm{~h}$ at room temperature (between 293.15 and $298.15 \mathrm{~K}$ ) at $230 \mathrm{rev} . / \mathrm{min}$. The fraction containing $2 \mathrm{Fe}-\mathrm{SOR}$ was collected as described for $D$. vulgaris rubredoxin. Two consecutive ionexchange chromatographic steps (DEAE-Sepharose $\mathrm{FF}^{\circledR}$ and Q-Sepharose $\mathrm{FF}^{\circledR}$; GE Healthcare) were applied. The fractions collected were analysed by UV-visible and SDS/PAGE, and pooled according to their purity. With this procedure it was possible to collect a final fraction containing SOR with a purity ratio of $6.2\left(A_{280} / A_{490}\right)$. All of these purification steps were performed at $277.15 \mathrm{~K}$ and $\mathrm{pH} 7.6$.

\section{Overexpression and purification of recombinant $D$. vulgaris Hildenborough Zn/Fe-SOR}

For D. vulgaris Hildenborough $\mathrm{Zn} / \mathrm{Fe}-\mathrm{SOR}$, the procedure was similar to the one described for $2 \mathrm{Fe}-\mathrm{SOR}$, although, in this case, both at the beginning and at the time of induction, $0.1 \mathrm{mM}$ $\mathrm{FeCl}_{2}$ and $0.1 \mathrm{mM} \mathrm{ZnCl}$ were added to the culture. The same chromatographic steps used for $2 \mathrm{Fe}-\mathrm{SOR}$ were used, and it was possible to collect a final fraction containing the pure $\mathrm{Zn} / \mathrm{Fe}-\mathrm{SOR}$ form with a purity ratio of $21\left(A_{280} / A_{644}\right)$.

\section{Metal content and protein quantification}

Metal content was determinated by induction-coupled plasma emission (Lab. de Análises, Dept. Química, CQFB/REQUIMTE, 
FCT/UNL). The protein concentration was determined using the Lowry assay with BSA as a protein standard [32].

The concentration of protein solutions were also determined spectrophotometrically using the reported molar absorption coefficients, $\varepsilon_{490 \mathrm{~nm}}=6.9 \mathrm{mM}^{-1} \cdot \mathrm{cm}^{-1}$ for $D$. vulgaris rubredoxin, $\varepsilon_{502 \mathrm{~nm}}=4.3 \mathrm{mM}^{-1} \cdot \mathrm{cm}^{-1}$ for D. vulgaris $\mathrm{SOR}_{\mathrm{Fe}(\mathrm{III})-\mathrm{Fe}(\mathrm{II})}, \varepsilon_{645 \mathrm{~nm}}=$ $1.9 \mathrm{mM}^{-1} \cdot \mathrm{cm}^{-1}$ for $D$. vulgaris $\mathrm{Zn} / \mathrm{Fe}-\mathrm{SOR}$ and $\varepsilon_{502 \mathrm{~nm}}=4.6$ $\mathrm{mM}^{-1} \mathrm{~cm}^{-1}$ for $D$. gigas desulforedoxin.

\section{Direct electron-transfer experiments}

Stopped-flow experiments were performed using a Bio-Logic SFM-300/S apparatus coupled with a MOS-250 optical system. All of the experiments were performed in anaerobic conditions in a glove box (UNILab, MBraun, less than 1 p.p.m.). All assays were performed in $50 \mathrm{mM}$ phosphate buffer at $\mathrm{pH} 7.6$ with $0.1 \mathrm{mM}$ EDTA at $283.15 \mathrm{~K}$. To perform the experiments, both rubredoxin and SOR were degassed in a Schlenk line before transfer to the glove box. Rubredoxin was then reduced with a slight excess of sodium dithionite. The $\mathrm{SOR}_{\mathrm{Fe}(\mathrm{III})-\mathrm{Fe}(\mathrm{II})}$ form was obtained by incubating As-purified SOR with a slight excess of ascorbic acid. The $\mathrm{SOR}_{\mathrm{Fe} \text { (III)-Fe(III) }}$ and $\mathrm{Zn} / \mathrm{Fe}-\mathrm{SOR}$ forms were prepared with an excess of sodium hexachloroiridate (IV) in order to obtain the fully oxidized form. Excess reagents (oxidants and reductants) were removed using a $5 \mathrm{ml}$ HiTrap $^{\mathrm{TM}}$ (GE Healthcare) desalting column. The data was best fitted with a second-order rate constant with $[\mathrm{Rd}]_{0}=[\mathrm{SOR}]_{0}$, where $[\mathrm{Rd}]_{\mathrm{ox}}$ is the amount of oxidized rubredoxin, $[\mathrm{Rd}]_{0}$ and $[\mathrm{SOR}]_{0}$ are the initial concentration of reduced rubredoxin and oxidized SOR respectively and $k^{\prime}=k$ $\left[\operatorname{Rd}_{\text {red }}\right]_{0}$, were $k$ is the second-order rate constant $[26,33]$.

$\left[\mathrm{Rd}_{\mathrm{ox}}\right]=\left[\mathrm{Rd}_{\mathrm{red}}\right]_{0}-\frac{\left[\mathrm{Rd}_{\mathrm{red}}\right]_{0}}{1+k^{\prime} \times t}$

\section{Spectroscopic and kinetic characterization}

Absorption spectra were collected with a Shimadzu UV-2101PC spectrophotometer, connected to a computer. Superoxidemediated electron-transfer assays were performed in a similar way (see the Supplementary Experimental section) as that previously published by Auchère et al. [31] at 296.15 K with a HewlettPackard 8452A diode-array spectrophotometer.

Data was fitted assuming that the reaction rate was proportional to the concentration of the reagents and a kinetic constant $k$. The concentration of both rubredoxin and superoxide used were significantly larger than SOR and so considered constant at $t=0$. The equation obtained was as follows:

$v_{0}=k^{\prime}[\mathrm{SOR}]$

where $k^{\prime}$ is

$k^{\prime}=k[\mathrm{Rd}]\left[\mathrm{O}_{2}^{\cdot-}\right]$

The value for $v_{0}$ was obtained directly from the experimental data and plotted against the corresponding amount of SOR.

\section{EPR spectroscopy}

EPR spectra were recorded on a Bruker EMX spectrometer equipped with a dual-mode cavity and an Oxford Instruments continuous flow cryostat. The experimental conditions used were: temperature $4.1 \mathrm{~K}$, microwave frequency $9.653 \mathrm{GHz}$, microwave power $2.002 \mathrm{~mW}$, modulation amplitude $1 \mathrm{mT}$, and receiver gain $1.26 \times 10^{5}$.

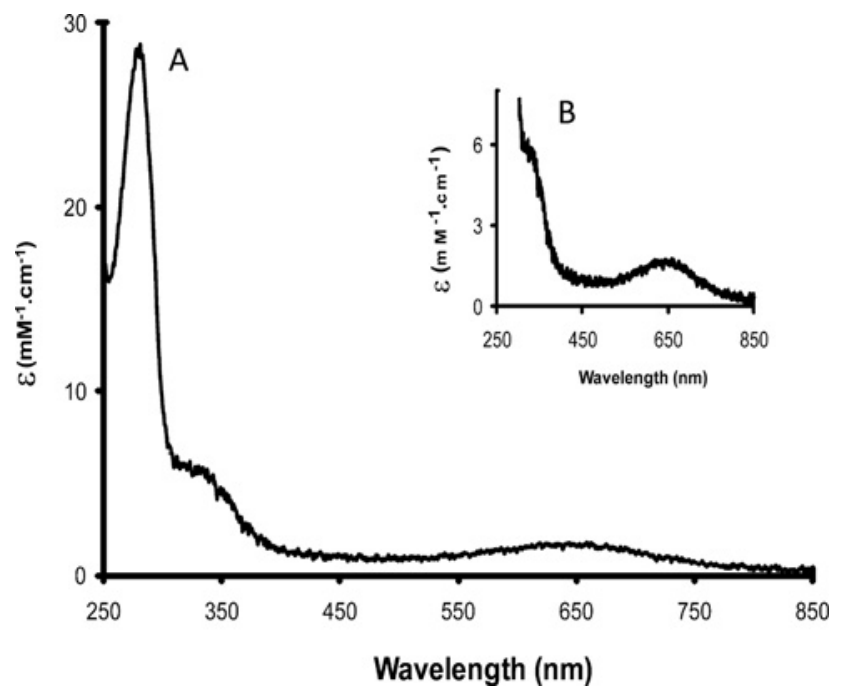

Figure 1 Absorbance spectrum for the oxidized form of the new Zn/Fe-SOR

(A) Absorbance spectrum, converted into the molar absorption coefficient, of the oxidized form of the new Zn/Fe-SOR. (B) Inset showing the absorption band at approximately $650 \mathrm{~nm}$, correspondening to ferric centre II.

\section{Electrochemical studies}

The potentiodynamic measurements were performed with a Potenciostat/Galvanostat $\mu$ AUTOLAB Type II. A glassy carbon disk (4 $\mathrm{mm}$ diameter) and a gold disk ( $3 \mathrm{~mm}$ diameter) were the working electrodes. The counter electrode was a platinum wire and an SCE (saturated calomel electrode) was used as a reference. The working electrodes were previously polished with 1.0 and $0.3 \mu \mathrm{m}$ alumina and immersed in Millipore water in an ultrasound bath for $5 \mathrm{~min}$ and finally thoroughly rinsed with Millipore water. The proteins were immobilized on the electrode using a cellulose membrane (Spectra/Por dialysis membrane, 3500 Da cut-off) that was fitted to the electrode with an o-ring, to obtain a thinlayer regime. The supporting electrolyte was $10 \mathrm{mM}$ Tris/ $\mathrm{HCl}$ buffer ( $\mathrm{pH} 7.6$ ), $0.1 \mathrm{M} \mathrm{KNO}$ and $20 \mathrm{mM} \mathrm{MgCl}_{2}$. The protein concentrations ranged from 150 to $300 \mu \mathrm{M}$. For each assay, $10 \mu \mathrm{l}$ of protein solution was used. In the membrane, together with the protein solution, $2 \mu \mathrm{l}$ of $2 \mathrm{mM}$ neomycin sulfate was added for the assays with the GC electrode. The gold electrode was

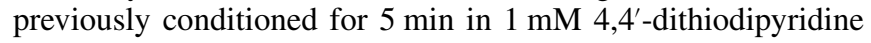
solution.

\section{RESULTS}

\section{Spectroscopic characterization}

Figure 1 shows a UV-visible spectrum of the $\mathrm{SOR}_{\mathrm{Zn} \text { (II)-Fe(III). The }}$ features presented by this new form of $D$. vulgaris Hildenborough SOR protein are very similar to those already known for class II and III SORs. The absorption spectrum has three main features, at $280 \mathrm{~nm}\left(\varepsilon_{280}=28650 \mathrm{M}^{-1} \cdot \mathrm{cm}^{-1}\right), 314 \mathrm{~nm}\left(\varepsilon_{314}=6089\right.$ $\left.\mathrm{M}^{-1} \cdot \mathrm{cm}^{-1}\right)$ and $644 \mathrm{~nm}\left(\varepsilon_{644}=1746 \mathrm{M}^{-1} \cdot \mathrm{cm}^{-1}\right)$. This $644 \mathrm{~nm}$ absorption band was previously assigned to centre II from $D$. vulgaris Hildenborough SOR and also for the oxidized form of the C-terminal domain DfxC of the recombinant SOR from $D$. vulgaris Hildenborough which contains only centre II [7,29,34]. The shoulder at approximately $314 \mathrm{~nm}$ should correspond to the cysteine-iron charge transfer band, also present in other proteins with similar iron centres [7,10,29,34,35]. 
Table 1 Second-order rate constants of electron transfer between reduced rubredoxin and the different SOR forms

\begin{tabular}{|c|c|c|c|c|}
\hline \multirow[b]{2}{*}{ Wavelength (nm) } & \multicolumn{4}{|c|}{ Second-order rate constant $\left[\times 10^{6}\left(\mathrm{M}^{-1} \cdot \mathrm{S}^{-1}\right)\right]$} \\
\hline & $\mathrm{SOR}_{\mathrm{Fe}(\mathrm{III})-\mathrm{Fe}(\mathrm{II})}$ & $\mathrm{SOR}_{\mathrm{Fe}(I I)-\mathrm{Fe}(\mathrm{III})}(1: 1)$ & $\mathrm{SOR}_{\mathrm{Fe}(\mathrm{III})-\mathrm{Fe}(\mathrm{III})}(2: 1)$ & $\mathrm{SOR}_{\mathrm{Zn}(\mathrm{II})-\mathrm{Fe}(\mathrm{III})}$ \\
\hline $\begin{array}{l}500 \\
650\end{array}$ & $28 \pm 4$ & $\begin{array}{l}4.3 \pm 1.9 \\
1.9+0.5\end{array}$ & $\begin{array}{l}1.3 \pm 0.2 \\
1.7+0.3\end{array}$ & $\begin{array}{l}3.2 \pm 1.5 \\
2.9+0.4\end{array}$ \\
\hline
\end{tabular}

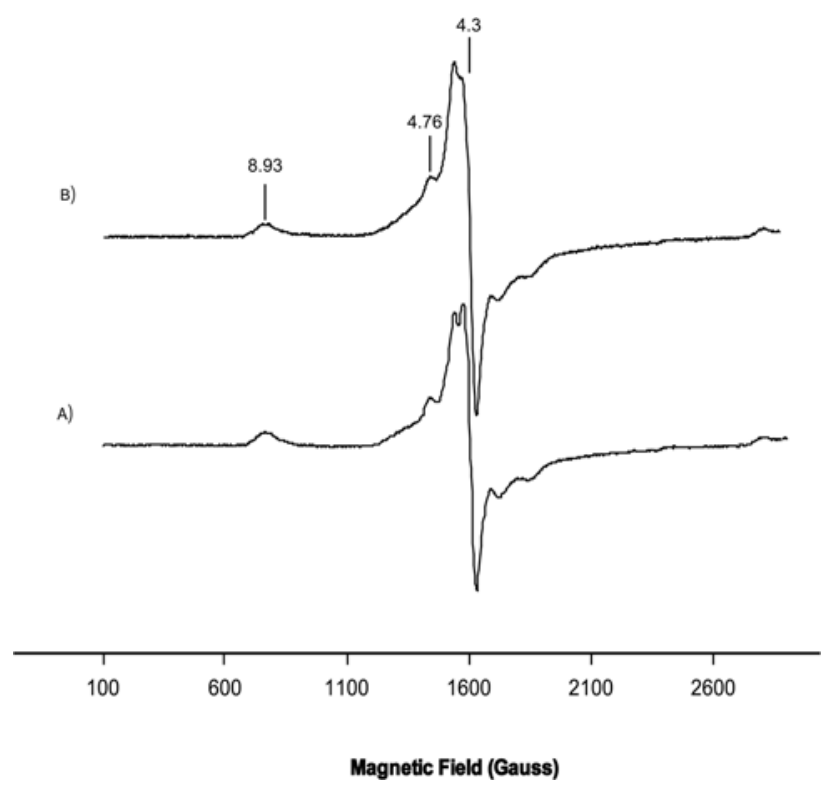

Figure 2 EPR spectra of Zn/Fe-SOR

(A) As-purified form and (B) oxidized form lby incubation with sodium hexachloroiridate (IV)] of $\mathrm{Zn} / \mathrm{Fe}-\mathrm{SOR}$. The experimental conditions used were: temperature $4.1 \mathrm{~K}$, microwave frequency $9.653 \mathrm{GHz}$, microwave power $2.002 \mathrm{~mW}$, modulation amplitude $1 \mathrm{mT}$ and receiver gain $1.26 \times 10^{5}$

Further spectroscopic characterization of $\mathrm{SOR}_{\mathrm{Zn}(\mathrm{II})-\mathrm{Fe}(\mathrm{III})}$ was performed by EPR in order to compare with the signals obtained for the iron-only form, $\mathrm{SOR}_{\mathrm{Fe}(\mathrm{III})-\mathrm{Fe}(\mathrm{III})}$. Figure 2 shows the EPR spectra of $\mathrm{SOR}_{\mathrm{Zn} \text { (II)-Fe(III) }}$ recorded at $4.2 \mathrm{~K}$. This spectrum is very similar to the one obtained with both $\mathrm{SOR}_{\mathrm{Fe}(\mathrm{III})-\mathrm{Fe}(\mathrm{III})}$ centre II and DfxC protein [7,29]. The dominant features at $g=8.93, g=4.76$ and $g=4.30$ are indicative of the presence of a ferric ion with a $S=5 / 2$ and E/D of approximately one-third [7,9,10,29].

\section{Metal analysis and $\mathrm{N}$-terminal sequence}

The amount of iron per protein, as well as the screening of other metals in the protein, was analysed by induction-coupled plasma emission (Lab. de Análises, Dept. Química, CQFB/REQUIMTE, FCT/UNL). The analysis performed pointed to a $1: 1$ ratio ( $\mathrm{Zn}$ and $\mathrm{Fe}$ atoms), and also did not reveal the presence of any other metal ions.

The protein was also subjected to sequential Edman degradation on an automatic protein sequencer (Applied Biosystem model LC491) and the N-terminal sequence of the first amino acid residues was determined. This ensured that the recombinant protein did not suffer an unexpected mutation/deletion in one or more centre I amino acid ligand. The analysis indicated that the first 21 amino acids had $100 \%$ identity when compared with the sequence predicted by the gene analysis.

\section{Direct electron-transfer measurements}

Direct electron transfer between reduced rubredoxin and the half-reduced form $\mathrm{SOR}_{\mathrm{Fe}(\mathrm{III})-\mathrm{Fe}(\mathrm{II})}$ was measured. The stopped-flow experiments were performed in a 1:1 ratio for the two proteins and monitored at $500 \mathrm{~nm}$ in order to follow the rubredoxin oxidation rate (see the Experimental section for further details). The kinetic traces were best fitted with a second-order kinetic rate constant with a $k$ of $(2.8 \pm 0.4) \times 10^{7} \mathrm{M}^{-1} \cdot \mathrm{s}^{-1}$, which corresponds to the electron-transfer rate constant from rubredoxin to $\mathrm{SOR}_{\mathrm{Fe}(\mathrm{III})-\mathrm{Fe}(\mathrm{II})}$ centre I. The same experimental procedure was applied for the assay between reduced rubredoxin and the fully oxidized form $\mathrm{SOR}_{\mathrm{Fe}(\mathrm{III}) \mathrm{Fe}(\mathrm{III})}$. In this case, the experiment was monitored at both 500 and $650 \mathrm{~nm}$, near the absorption maxima of both oxidized rubredoxin and $\mathrm{SOR}_{\mathrm{Fe} \text { (III)-Fe(III) }}$ centre II respectively. The second-order rate constants calculated for both wavelengths were $(4.3 \pm 1.9) \times 10^{6} \mathrm{M}^{-1} \cdot \mathrm{s}^{-1}$ and $(1.9 \pm 0.5) \times 10^{6} \mathrm{M}^{-1} \cdot \mathrm{s}^{-1}$, for 500 and $650 \mathrm{~nm}$ respectively (Table 1 ). These values were considered identical within the experimental error. These values are also close to the values published for the electron transfer between rubredoxin- 1 and -2 , and centre II of class I SOR from A. fulgidus $\left(1.9 \times 10^{6} \mathrm{M}^{-1} \cdot \mathrm{s}^{-1}\right.$ and $2.4 \times 10^{6} \mathrm{M}^{-1} \cdot \mathrm{s}^{-1}$ respectively) [14], and for the reduction of centre II of the SOR mutant C13S from D. vulgaris Hildenborough, $1.2 \times 10^{6} \mathrm{M}^{-1} \cdot \mathrm{s}^{-1}$ [27]. In contrast, when Neelaredoxin (class II SOR) from A. fulgidus is reduced by ribredoxin- 1 and -2 , the authors report two second-order rate constants of $1 \times 10^{7} \mathrm{M}^{-1} \cdot \mathrm{s}^{-1}$ and $6 \times 10^{7} \mathrm{M}^{-1} \cdot \mathrm{s}^{-1}$ respectively [26].

Nevertheless, in this case, and as described for the reduction of oxidized SOR from A. fulgidus [14], the absorbance measured at $500 \mathrm{~nm}$, at the end of the experiment and considering the concentration of both proteins after mixing, was due to the contribution of both oxidized rubredoxin and $\mathrm{SOR}_{\mathrm{Fe}(\mathrm{III})-\mathrm{Fe}(\mathrm{II})}$, which was obtained after the one electron reduction. Two possibilities arise from this observation: (i) electrons are donated by rubredoxin to centre I and then, by a fast intramolecular electron-transfer process, will reduce centre II which gives rise to an oxidized centre I at the end of the experiment, or (ii) rubredoxin donated electrons directly to centre II, keeping centre I in the oxidized form, as has been proposed previously [14].

However, this observation brings to the fore the question about the exact location of where electron transfer occurs, or even if there is some type of intramolecular electron transfer. To further understand the electron-transfer process, a similar experiment was performed, but with a 2:1 rubredoxin/SOR $\mathrm{Se}_{\mathrm{Fe}(\mathrm{III}) \mathrm{Fe}(\mathrm{III})}$ ratio.

The calculated second-order rate constant values were $(1.3 \pm 0.2) \times 10^{6} \mathrm{M}^{-1} \cdot \mathrm{s}^{-1}$ and $(1.7 \pm 0.3) \times 10^{6} \mathrm{M}^{-1} \cdot \mathrm{s}^{-1}$ at $500 \mathrm{~nm}$ and $650 \mathrm{~nm}$ respectively. In this case, the fully oxidized form of rubredoxin is achieved with the concomitant conversion of SOR into the reduced form, meaning that complete SOR reduction is possible within a stopped-flow time scale when enough electrons are provided. The similarity of these two values is the first evidence of a possible intramolecular electron transfer, since a biphasic behaviour would be expected at $500 \mathrm{~nm}$ if rubredoxin was able to donate electrons independently to centre I 


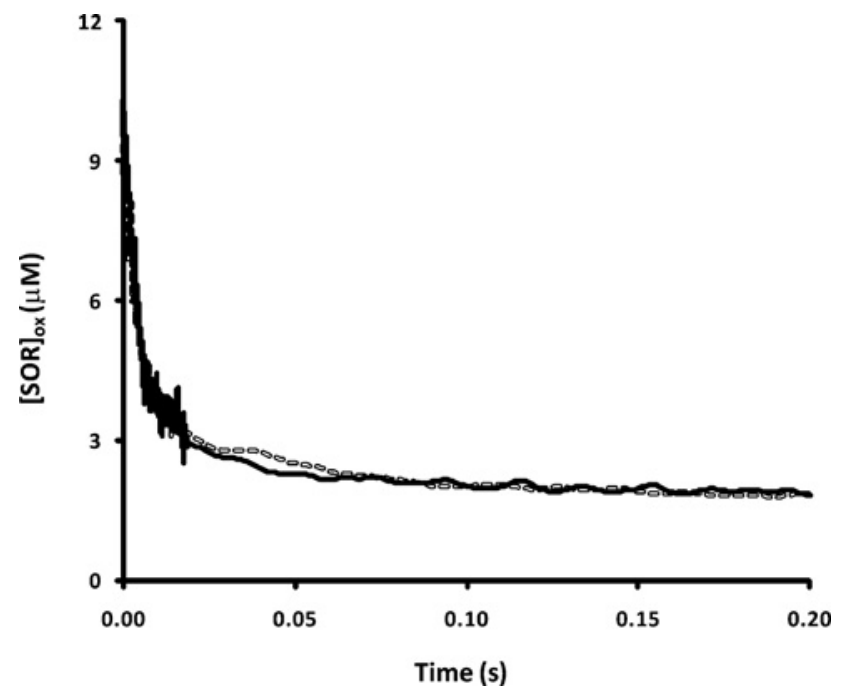

Figure 3 Stopped-flow kinetics of the reduction of $\mathrm{SOR}_{\mathrm{Zn}(\mathrm{II})-\mathrm{Fe}(\mathrm{III})}$ and $\mathrm{SOR}_{\mathrm{Fe}(\mathrm{III}) \mathrm{Fe}(\mathrm{III})}$

Comparison of stopped-flow kinetics of the reduction of $\mathrm{SOR}_{\mathrm{Zn}(\mathrm{III}-\mathrm{Fe}(\mathrm{III})}$ by reduced rubredoxin (continuous line) and $\mathrm{SOR}_{\mathrm{Fe}(\mathrm{III}) \text {-Fe(III) }}$ form by reduced rubredoxin (broken line). The variation was measured by the absorbance changes at $650 \mathrm{~nm}$ and converted into the concentration. Each trace was recorded in three integration time steps $(0.01,1$ and $100 \mathrm{~ms})$, in order to get better resolution at the beginning of the experiment.

or centre II, considering the 10 -fold difference between the obtained values in the previous experiments for reduction of centre I in $\mathrm{SOR}_{\mathrm{Fe} \text { (III)-Fe(II) }}$ and centre II in $\mathrm{SOR}_{\mathrm{Fe} \text { (III)-Fe(III) }}$. The absence of this biphasic behaviour supports the idea that when both SOR centres are oxidized, the electrons follow a pathway that goes through centre I to centre II.

To calculate the electron-transfer rate constant of the isolated centre II, the same experiments were repeated, but this time mixing reduced rubredoxin with oxidized $\mathrm{SOR}_{\mathrm{Zn} \text { (II)-Fe(III) }}$ in a $1: 1$ ratio between the two proteins. As a result, the calculated values at both wavelengths were $(3.2 \pm 1.5) \times 10^{6} \mathrm{M}^{-1} \cdot \mathrm{s}^{-1}$ and $(2.9 \pm 0.4) \times 10^{6} \mathrm{M}^{-1} \cdot \mathrm{s}^{-1}$ for $500 \mathrm{~nm}$ and $650 \mathrm{~nm}$ respectively. Again, these values can be considered similar within the experimental error, and they are also similar to the ones obtained for $\mathrm{SOR}_{\mathrm{Fe}(\mathrm{III})-\mathrm{Fe}(\mathrm{III})}$ (Figure 3). This experiment proves that reduced rubredoxin is able to reduce centre II of SOR, but at a lower rate constant than centre I of the same protein.

\section{Electron-transfer measurements in the presence of superoxide anion}

Superoxide reductase activity

A superoxide-mediated electron-transfer assay was performed in a way similar to that previously published by Auchère et al. [31] (see the Experimental section for further details). In this experiment the initial reaction rate was used to differentiate the reaction constants obtained when different forms of SOR are used. As was previously described by Auchère et al. [31], the results show that, also in the superoxide-mediated electron-transfer process, a higher rubredoxin oxidation rate is obtained when the $\mathrm{SOR}_{\mathrm{Fe}(\mathrm{III})-\mathrm{Fe}(\mathrm{II})}$ form is used $\left(12.34 \pm 0.08 \mathrm{~min}^{-1}\right)$, whereas the reaction rates calculated when $\mathrm{SOR}_{\mathrm{Fe}(\mathrm{III})-\mathrm{Fe}(\mathrm{III})}$ and $\mathrm{SOR}_{\mathrm{Zn} \text { (II)-Fe(III) }}$ were used are $9.72 \pm 0.06$ $\mathrm{min}^{-1}$ and $8.98 \pm 0.04 \mathrm{~min}^{-1}$ respectively (Figure 4). Despite the differences in the assays, as well as their different purpose, these observations point out the same trend as the results obtained for direct electron-transfer experiments. Thus it is possible to speculate that $\mathrm{SOR}_{\mathrm{Fe}(\mathrm{III})-\mathrm{Fe}(\mathrm{II})}$ is not only able to receive electrons faster than the other forms, but also it is catalytically more efficient. This effect could be related to the reduced state of centre II in the beginning of the reaction. To test this observation, a new experiment was performed using both $\mathrm{SOR}_{\mathrm{Fe}(\mathrm{II}) \mathrm{Fe}(\mathrm{II})}$ and $\mathrm{SOR}_{\mathrm{Zn} \text { (II)-Fe(II) }}$ forms. In this case, the calculated rate constants were comparable with each other $\left(11.79 \pm 0.86 \mathrm{~min}^{-1}\right.$ and $12.12 \pm 0.73$ $\mathrm{min}^{-1}$ for $\mathrm{SOR}_{\mathrm{Fe}(\mathrm{II})-\mathrm{Fe}(\mathrm{II})}$ and $\mathrm{SOR}_{\mathrm{Zn} \text { (II)-Fe(II) }}$ respectively), and with the $\mathrm{SOR}_{\mathrm{Fe}(\mathrm{III}) \mathrm{Fe}(\mathrm{II})}$ form. A summary of all of the values obtained is shown in Table 2.

The results of this last experiment suggest that when the catalytic reaction is assayed starting with centre II in the reduced state, the presence of centre $\mathrm{I}$ is not relevant for catalysis. The smaller reaction rate constants observed for the $\mathrm{SOR}_{\mathrm{Fe}(\mathrm{III}) \mathrm{Fe}(\mathrm{III})}$ and oxidized $\mathrm{SOR}_{\mathrm{Zn} \text { (II)-Fe(III) }}$ forms are in accordance with this observation, since in both cases centre II has to be reduced prior to the reaction with superoxide radical, leading to a slower initial reaction rate.

\section{Electrochemical measurements}

The electrochemical features of the D. gigas desulforedoxin, D. vulgaris Hildenborough rubredoxin, and native and modified forms of SOR proteins were observed by cyclic- and SW (squarewave) voltammetry. Both desulforedoxin and rubredoxin present well-defined current peaks, in quasi-reversible behaviour, due to a one electron transfer at the redox centre $\left[\mathrm{Fe}(\mathrm{S}-\mathrm{Cys})_{4}\right]^{3+} /[\mathrm{Fe}(\mathrm{S}$ Cys) $\left.)_{4}\right]^{2+}$. Figure 5 shows the typical behaviour of these two proteins at $288.15 \mathrm{~K}$. The calculated values for the formal redox potential of these centres were $-27 \pm 2$ and $+39 \pm 2 \mathrm{mV}$ for desulforedoxin and rubredoxin respectively. The value calculated for rubredoxin is in agreement with previous published results obtained on graphite microelectrodes [36].

The electrochemical pattern observed for $2 \mathrm{Fe}-\mathrm{SOR}$ is not so straightforward. Although there are structural similarities found between centre I of this protein and both desulforedoxin and rubredoxin centres, its redox behaviour is more complex. In fact, different features are observed with slow and fast scan rates. Typically, in the range $10-20 \mathrm{mV} / \mathrm{s}$ or higher scan rates, two very close redox processes are visible, although with low definition. At lower scan rates, only one redox process is observed, with the anodic and cathodic peaks possessing a large peak width, leading to the conclusion that redox processes become merged and are better seen at higher scan rate potentials. Also, with the temperature increase, the merging of the processes is also observed at increasingly higher scan rates. A typical example of this different behaviour at low temperature $(278.15 \mathrm{~K})$ and a better view of the merging of the two peaks at higher temperature $(298.15 \mathrm{~K})$ is shown in Figure 6. The proximity of the potential values at which these two apparent redox processes are observed and the merging with the change in the applied potential scan rate and temperature, seems to suggest that both processes are due to centre I, corresponding to a single electron-transfer process. An estimation of the number of electrons involved through the current peak width at half height also points to this hypothesis. One possible explanation of this phenomenon is associated with different heterogeneous electron-transfer constants for the same process. This has already been reported by other authors, although in different systems and conditions [37]. In fact, superficial charge calculations performed with Accelrys DS Visualizer version 2.0.1.7347 (Accelrys Software) shows that 2Fe-SOR does not have a preferential positive or negative superficial electrostatic charge, in contrast with what is observed for desulforedoxin and rubredoxin proteins (see Figure 7). 

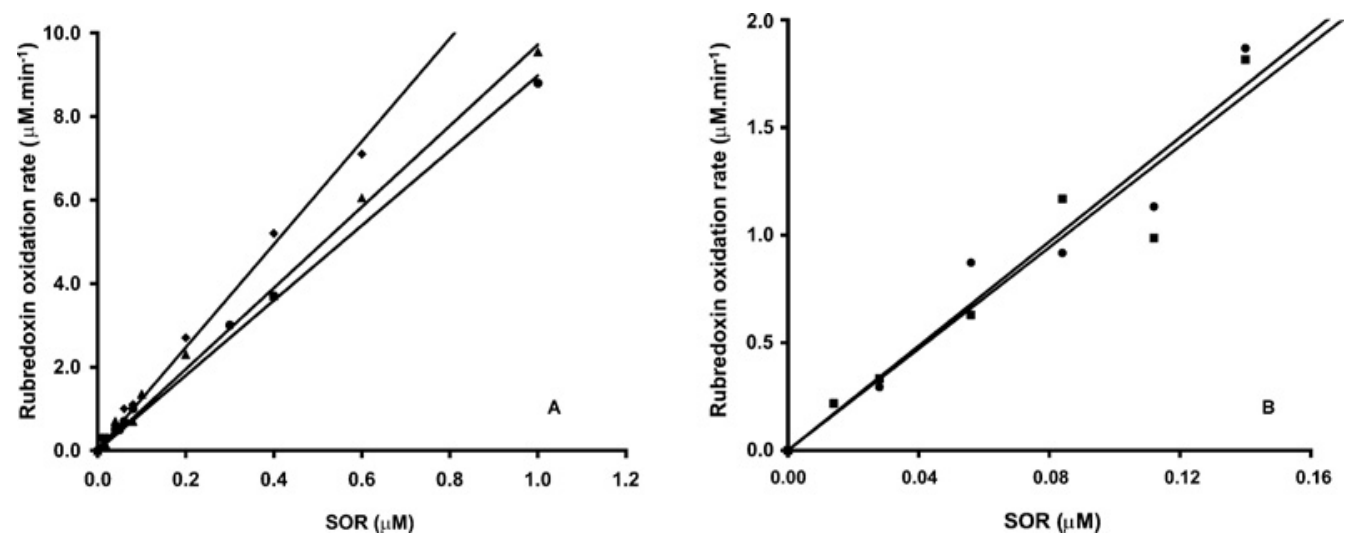

Figure 4 Representation of the rubredoxin oxidation rate by superoxide-mediated electron transfer

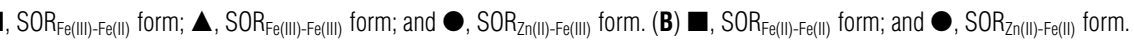

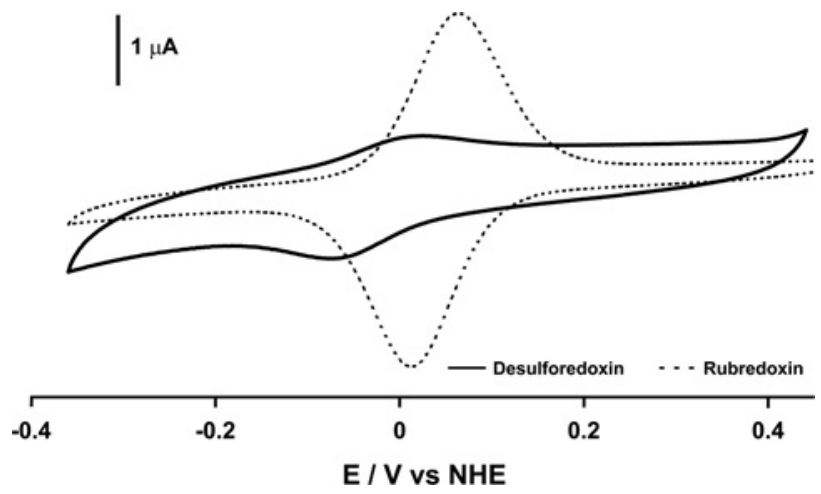

Figure 5 Electochemical behaviour of desulforedoxin and rubredoxin

Comparison between the typical cyclic voltammograms of desulforedoxin and rubredoxin at the same experimental conditions, using a glassy carbon working electrode $(\mathrm{pH} 7.6, T=288.15 \mathrm{~K}$, $v=20 \mathrm{mV} / \mathrm{s})$.

This may result in a non-preferential protein orientation towards the electrode surface, even with the addition of a positive-charged promoter, which may originate different electronic pathways to the redox centre and different heterogeneous electronictransfer constants, producing two apparent redox processes. Partial adsorption of the biomolecules could also contribute to this hypothesis of apparent dispersion of heterogeneous constant rates. However, the control experiments, performed following the assays at the same conditions, after the electrode was washed in Millipore ${ }^{\circledR}$ water and then immersed in the same electrolyte solution, without protein, have shown no apparent adsorption.

Another hypothesis is related to the electrochemical mechanism of the $2 \mathrm{Fe}-\mathrm{SOR}$ reduction. These two apparent redox processes can occur from two different electron-transfer pathways in the SOR reduction, including an intramolecular step, with one electron transfer from centre I to centre II. This explanation is in agreement with centre II data, from both $2 \mathrm{Fe}-\mathrm{SOR}$ and $\mathrm{Zn} / \mathrm{Fe}$ SOR proteins, observed by fast electrochemical techniques and will be discussed in more detail later.

The formal potential of the three proteins, desulforedoxin, $2 \mathrm{Fe}$ SOR and rubredoxin, was estimated in the range from 278.15 to $290.15 \mathrm{~K}$ in order to establish its temperature-dependence (Figure 8). Both desulforedoxin and rubredoxin presented lower slopes and considerably lower associated errors than $2 \mathrm{Fe}-\mathrm{SOR}$. The values used to evaluate the $2 \mathrm{Fe}-\mathrm{SOR}$ formal redox potential

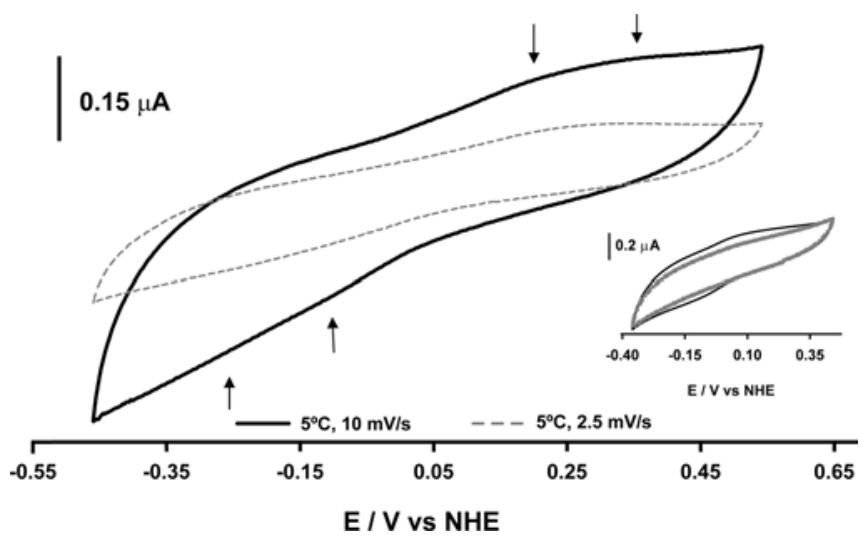

Figure 6 2Fe-SOR electrochemical behaviour

$2 \mathrm{Fe}-\mathrm{SOR}$ redox behaviour on glassy carbon working electrode, showing the apparent merging of two redox processes at $278.15 \mathrm{~K}$, indicated by the arrows. Inset: the same experiment at $298.15 \mathrm{~K}$ and $20 \mathrm{mV} / \mathrm{s}$.

of centre I were taken from the assays where the two processes were merged, resulting in $\mathrm{E}^{0 \prime}=+32 \pm 11 \mathrm{mV}$ for $288.15 \mathrm{~K}$. This explains the larger dispersion of the values and so the larger error associated with this protein on $\mathrm{E}^{0 /}$ compared with the associated errors resulting from desulforedoxin and rubredoxin. Also, the $2 \mathrm{Fe}-\mathrm{SOR}$ centre I redox potential value is in agreement with the results obtained for the recombinant DfxN published previously [29].

The Gibbs free energy of the electron-transfer reaction can be estimated from the dependence of the redox potential of the centres on the temperature, and can be related to redox state conformational changes, among other factors, such as the bonding interaction at the metallic centres [38]. As the three proteins under study have the same type of metallic centres, the differences on the variations of the free energy, $\Delta G^{0 \prime}$, are assumed to be mainly related to conformational changes (that occur with the redox state change) and will be analysed without discrimination of the different components of the Gibbs energy.

The estimated $\Delta \mathrm{G}^{0 \prime}$ values of the three proteins, taken from the slopes of the $\mathrm{E}^{0 \prime}$ against $T$ plot, were, for desulforedoxin, rubredoxin and 2Fe-SOR, 1.66, 2.41 and $5.25 \mathrm{~kJ} \cdot \mathrm{mol}^{-1}$ respectively. From these values, and taking into account previous assumptions, it could be inferred that $2 \mathrm{Fe}-\mathrm{SOR}$ is the one protein where more pronounced conformational changes occur. 


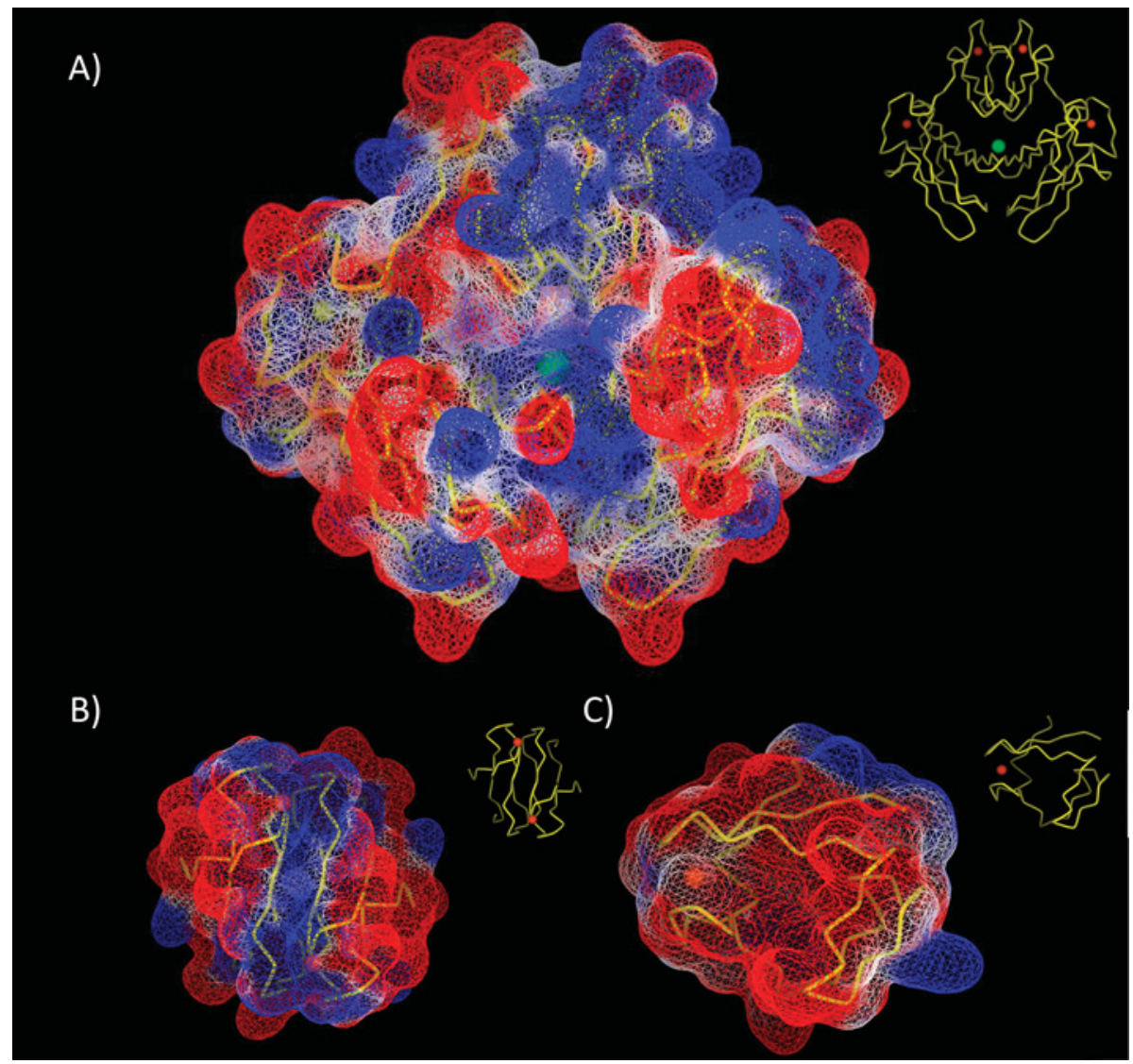

Figure 7 Superficial charge calculated for SOR, rubredoxin and desulforedoxin

Superficial charge calculated by Poisson-Boltzmann for: (A) D. desulfuricans A.T.C.C. 27774 SOR (PDB code 1DFX), (B) D. gigas desulforedoxin (PDB code 1DSG) and (C) D. vulgaris rubredoxin (PDB code 1RB9). Blue indicates positive charge, and red indicates negative charge. The calculations were performed using Accelrys DS Visualizer version 2.0.1.7347 (Accelrys Software).

Table 2 Apparent rate constants, $\boldsymbol{k}^{\prime}$, calculated for the superoxidemediated electron transfer between rubredoxin and all SOR forms

\begin{tabular}{ll}
\hline SOR form & $k^{\prime}\left(\mathrm{min}^{-1}\right)$ \\
\hline SOR & $12.34 \pm 0.08$ \\
SOR $_{\text {Fe(IIII)-Fe(III) }}$ & $9.72 \pm 0.06$ \\
SOR & $8.98 \pm 0.04$ \\
SOR $_{\text {Fe(I)-Fe(III) }}$ & $11.79 \pm 0.86$ \\
SOR $_{Z n(I I)-F e(I I)}$ & $12.12 \pm 0.73$ \\
\hline
\end{tabular}

The electrochemical behaviour of $\mathrm{Zn} / \mathrm{Fe}-\mathrm{SOR}$ was studied by cyclic voltammetry and its behaviour compared with $2 \mathrm{Fe}-$ SOR. The results are shown in Figure 9. As shown, the $\mathrm{Zn} / \mathrm{Fe}-$ SOR centre $\mathrm{I}$ is redox inactive, which proves that zinc has been successfully incorporated into the protein, but also that the redox signal observed close to $0 \mathrm{~V}$ compared with NHE (normal hydrogen electrode) in $2 \mathrm{Fe}-\mathrm{SOR}$ can be definitely indexed to centre I, and is also in agreement with the DfxN behaviour previously published [29]. Moreover, the electrochemical results are in agreement with those previously described which show that the $\mathrm{Zn} / \mathrm{Fe}-\mathrm{SOR}$ sample is homogeneous.

DP (differential pulse) and SW voltammetry were used to test the behaviour of $2 \mathrm{Fe}-\mathrm{SOR}$, starting from different potential values, corresponding to the initial protein oxidation states and same window of observation. The aim was to observe the existence

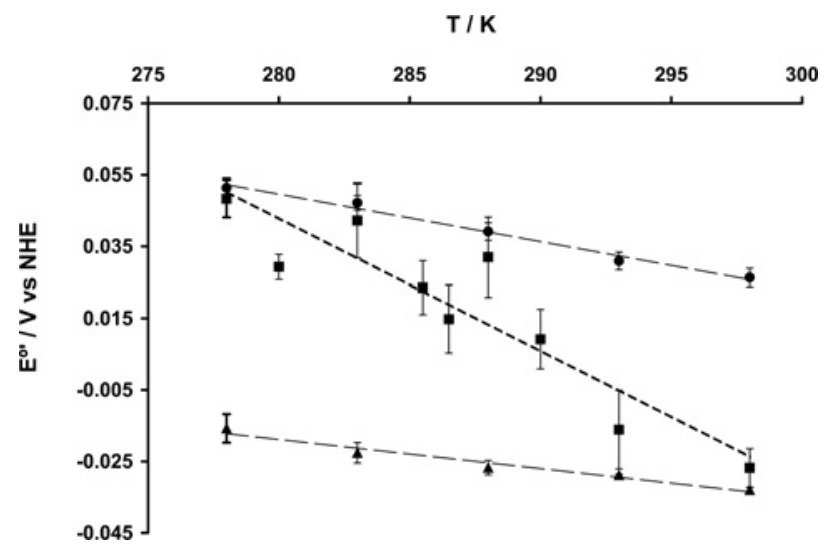

Figure 8 Dependence of formal potential values on the temperature

From the formal potential values obtained for the three proteins, desulforedoxin $(\boldsymbol{\Delta}), 2 \mathrm{Fe}-\mathrm{SOR}$ $(\mathbf{\square})$ and rubredoxin $(\mathbf{O})$, it was possible to estimate the Gibbs energy variation.

of differences in the protein electrochemical patterns depending on the initial redox starting point. DP voltammetry assays, in the potential range between 0.352 and $-0.254 \mathrm{~V}$ (cathodic direction), confirmed the previous cyclic voltammetry results, showing the presence of centre I on 2Fe-SOR $\left(E_{1 / 2}=13 \mathrm{mV}\right.$ compared with NHE) and the absence of the corresponding signal on 


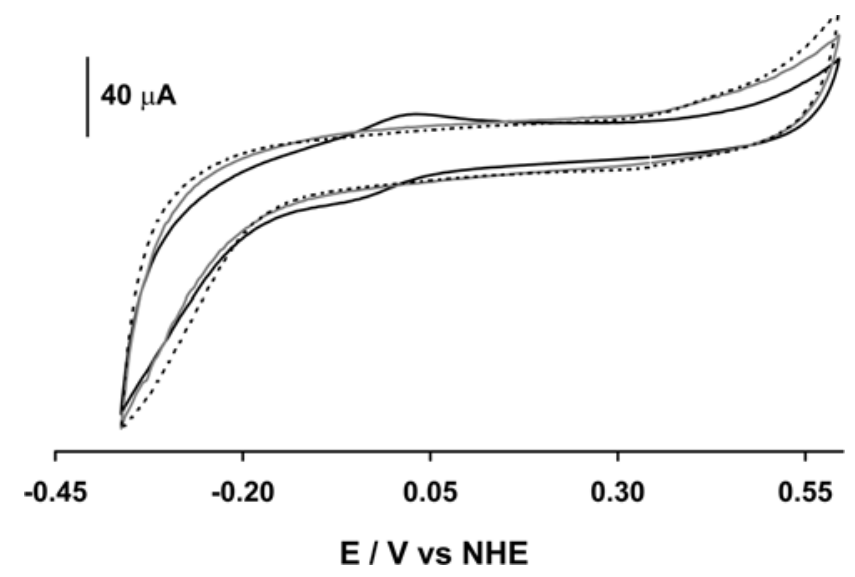

Figure 9 Redox behaviour comparison between $2 \mathrm{Fe}-\mathrm{SOR}$ and $\mathrm{Zn} / \mathrm{Fe}-\mathrm{SOR}$

Plot of the comparison between the electrochemical behaviour of 2Fe-SOR (black line) and $\mathrm{Zn} / \mathrm{Fe}-\mathrm{SOR}$ (grey line) for the same experimental conditions (room temperature, $v=10 \mathrm{mV} / \mathrm{s}$ ). The broken line is the control (glassy carbon).

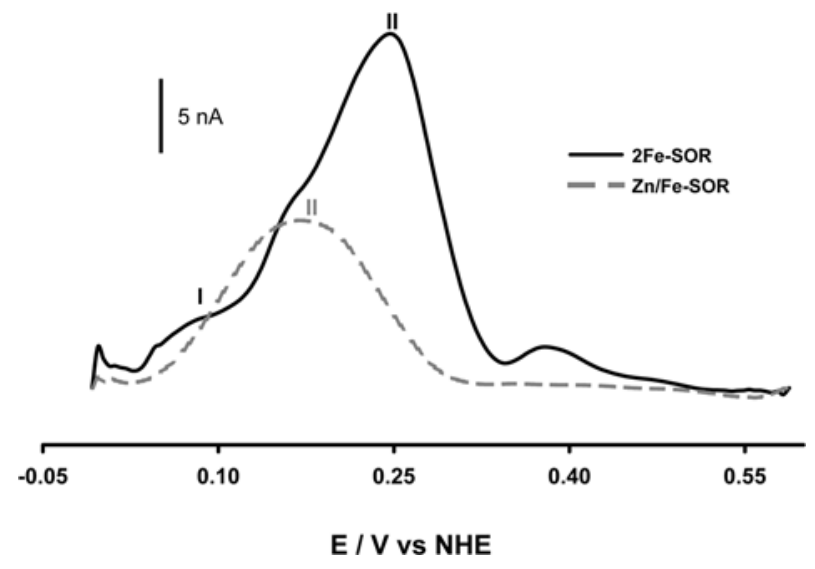

Figure 10 SW voltammograms of the 2Fe-SOR and Zn/Fe-SOR

SW voltammetry records of the $2 \mathrm{Fe}-\mathrm{SOR}$ and $\mathrm{Zn} / \mathrm{Fe}-\mathrm{SOR}$ proteins scanned in the anodic direction. Experimental parameters: room temperature, gold working electrode, step potential of $5 \mathrm{mV}$, amplitude of $20 \mathrm{mV}$, frequency of $8 \mathrm{~Hz}$ and $v=40 \mathrm{mV} / \mathrm{s}$. The current peaks of centre I and II are marked. A more anodic peak current, observed close to $0.4 \mathrm{~V}$, is not related to the protein centre and is due to interference.

$\mathrm{Zn} / \mathrm{Fe}-\mathrm{SOR}$. The SW voltammetry technique revealed better results in the anodic scanning direction than DP voltammetry, allowing better comparison between the potential values obtained in each scanning direction. The results have shown some differences in the centre I current peak positions, depending of the potential scanning direction. From the results, the $E^{\circ \prime}$ of $2 \mathrm{Fe}-\mathrm{SOR}$ centre $\mathrm{I}$ was estimated to be $-25 \mathrm{mV}$ and $+79 \mathrm{mV}$ compared with NHE, when the potential scan was started at the cathodic and anodic direction respectively, which corresponds to the oxidized and reduced initial states of the protein (see Figure 10 and Supplementary Figure S1 at http://www.BiochemJ.org/bj/438/bj4380485add.htm). This may be indicative of centre I conformational changes between the reduced and oxidized states, and, consequently, to the difference in the observed redox potential [33,39].

In addition, using SW voltammetry it was possible, for the first time, to observe the redox signal of $2 \mathrm{Fe}-\mathrm{SOR}$ centre II. Figure 10 shows the comparison between $2 \mathrm{Fe}-\mathrm{SOR}$ and $\mathrm{Zn} / \mathrm{Fe}-\mathrm{SOR}$ scanned in the anodic direction. Three signals observed in the $2 \mathrm{Fe}-\mathrm{SOR}$ SW voltammograms were considered to be significant. Two of these signals were assigned as corresponding to centres I and II respectively, based on $\mathrm{CV}$ results for centre I on both forms as shown in the Figure 9. For $\mathrm{Zn} / \mathrm{Fe}-\mathrm{SOR}$ only one signal is observed, which must correspond to centre II. It should be emphasized that, unlike centre I which presents a stable signal with time, it is only possible to detect centre II in the first scan and in the anodic direction. It seems that this centre suffers an irreversible change after the potential sweep, and it is always necessary to use a fresh preparation on the electrode to be able to observe this second process. The estimated values of the $E^{\mathrm{o} \prime}$ for $2 \mathrm{Fe}-\mathrm{SOR}$ and $\mathrm{Zn} / \mathrm{Fe}-\mathrm{SOR}$ centre II are $+255 \mathrm{mV}$ and $+167 \mathrm{mV}$ respectively. Previously published work with DfxC [29], also pointed to a signal due to centre II of $247 \mathrm{mV}$ which is in agreement with the results of the present study with all proteins.

The third current peak observed in the potential range between processes I and II in $2 \mathrm{Fe}-\mathrm{SOR}$ could result from the differences in the dispersion of the electron-transfer rate constants, as discussed above for $2 \mathrm{Fe}-\mathrm{SOR}$. However, in the present study, both $2 \mathrm{Fe}-\mathrm{SOR}$ and $\mathrm{Zn} / \mathrm{FeSOR}$ are being scanned in the same potential region, using the same technique and experimental conditions. If the dispersion of the electron constant rate, due to the protein surface charge, is the cause of the signal observed, this should also be visible in the $\mathrm{Zn} / \mathrm{FeSOR}$ data. Such a phenomenon reinforces the hypothesis of an intramolecular electron transfer between centre I and II.

The electrochemical mechanism, in accordance with these data, implies not only the direct electron transfer between $2 \mathrm{Fe}-\mathrm{SOR}$ and the electrode, but also an intramolecular electron transfer. [A first electron transfer to/from the protein, direct to centre I, promotes the conversion between redox states, for example, $\mathrm{SOR}_{\mathrm{Fe}(\mathrm{III})-\mathrm{Fe}(\mathrm{III})}$ into $\mathrm{SOR}_{\mathrm{Fe}(\mathrm{II})-\mathrm{Fe}(\mathrm{III})}$, and a subsequent second direct electron transfer (to centre II) leads to the conversion between $\mathrm{SOR}_{\mathrm{Fe}(\mathrm{II}) \mathrm{Fe}(\mathrm{III})}$ and $\left.\mathrm{SOR}_{\mathrm{Fe}(\mathrm{II})-\mathrm{Fe}(\mathrm{II})}\right]$. From the data, the electronic pathway must involve a first direct electrode electron transfer with the protein to centre I, promoting a transient $\mathrm{SOR}_{\mathrm{Fe}(\mathrm{II})-\mathrm{Fe}(\mathrm{III})}$ state, followed by a partial intramolecular electron transfer between centre I and centre II, leading to a mixture of $\mathrm{SOR}_{\mathrm{Fe}(\mathrm{II})-\mathrm{Fe}(\mathrm{III})}$ and $\mathrm{SOR}_{\mathrm{Fe}(\mathrm{III})-\mathrm{Fe}(\mathrm{II})}$ states. A second electron reduction can occur directly either to centre I or to centre II. However, the $\mathrm{SOR}_{\mathrm{Fe}(\mathrm{III})-\mathrm{Fe}(\mathrm{II})}$ state will probably need a lower driving force to be interconverted into $\mathrm{SOR}_{\mathrm{Fe}(\mathrm{II})-\mathrm{Fe}(\mathrm{II})}$. This would cause a split in the centre II peak, observed in Figure 10, and the appearance of a 'pre-peak', corresponding to the redox state $\mathrm{SOR}_{\mathrm{Fe} \text { (II)-Fe(II) }}$ of the protein resulting from the intramolecular electron transfer. The continuous potential increase, by the direct electron transfer to the protein, directly to centre II, will also result in the $\mathrm{SOR}_{\mathrm{Fe}(\mathrm{II})-\mathrm{Fe} \text { (II) }}$ state, whereas the remaining molecular population is still in the $\mathrm{SOR}_{\mathrm{Fe}(\mathrm{II}) \mathrm{Fe}(\mathrm{III})}$ redox state. Figure 11 shows a schematic representation to simplify the hypothesis described, comparing the electronic pathways in $2 \mathrm{Fe}-\mathrm{SOR}$.

Pathway 1 is observed in $2 \mathrm{Fe}-\mathrm{SOR}$ data, corresponding respectively to the current peaks named in Figure 10 as centre I, 'pre-peak' of centre II and centre II, where the 'pre-peak' is indeed the result of the reduction of the $\mathrm{SOR}_{\mathrm{Fe}(\mathrm{II})-\mathrm{Fe}(\mathrm{III})}$ redox state resulting from the previous intramolecular electron transfer (a small, more positive, current peak in the $2 \mathrm{Fe}-\mathrm{SOR}$ scan is also visible, but this should correspond to some amino acid oxidation or some oxide formation and it is believed not to be related to the metal centre of the protein). Pathway 2 is a simulation of a second reduction directly to centre II, which is similar to the case of $\mathrm{Zn} / \mathrm{Fe}-\mathrm{SOR}$ electron transfer (in Figure 10, referred to as II) from the electrode to the protein centre II. In this case, as $\mathrm{Zn}$ (II) is electrochemically inactive, at the experimental potential window, centre $\mathrm{I}$ is not able to participate in any intramolecular electron transfer; therefore, with $\mathrm{Zn} / \mathrm{Fe}-\mathrm{SOR}$, only one current peak is visible. 


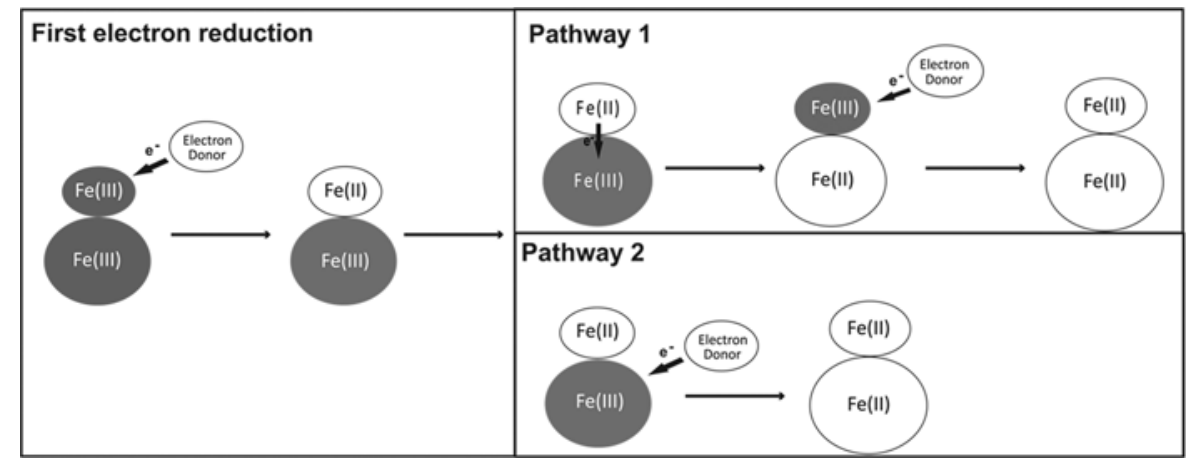

\section{Figure 11 Proposed mechanisms for the electron-transfer pathway between 2Fe-SOR and rubredoxin}

Proposed mechanisms for the electron-transfer pathway between 2Fe-SOR and its physiological redox partner, rubredoxin. Pathway 1 involves an intramolecular electron transfer from centre I to centre II and then the entrance, to centre I of a second electron, resulting in a fully reduced SOR. Pathway II involves a second electron transfer directly to centre II, resulting in a fully reduced SOR. Common to both pathways is the first electron transfer that occurs in centre I.

\section{DISCUSSION}

The new $\mathrm{Zn} / \mathrm{Fe}-\mathrm{SOR}$ form revealed some spectroscopic features similar to class II and III SORs, such as the UV-visible and EPR spectra. On the other hand, primary structure analysis proved that this protein was identical with the native $D$. vulgaris Hildenborough SOR.

The experiments performed focusing on the direct electron transfer between rubredoxin and the three different forms of $\mathrm{SOR}\left[\mathrm{SOR}_{\mathrm{Fe} \text { (III)-Fe(II) }}, \mathrm{SOR}_{\mathrm{Fe} \text { (III)-Fe(III) }}\right.$ and $\mathrm{SOR}_{\mathrm{Zn} \text { (II)-Fe(III) }}$ revealed the existence of electron-transfer processes. The kinetic rate constants calculated for both $\mathrm{SOR}_{\mathrm{Fe}(\mathrm{III})-\mathrm{Fe}(\mathrm{III})}$ and $\mathrm{Zn} / \mathrm{Fe}-\mathrm{SOR}$ forms were comparable with previously published data, but a 10-fold increase was observed in the $\mathrm{SOR}_{\mathrm{Fe}(\mathrm{III})-\mathrm{Fe}(\mathrm{II})}$ form, suggesting an easier reduction of centre I [14,26,27,40,41]. In a first approach, this could mean that the preferential electron-transfer pathway from rubredoxin to SOR is through centre I.

Nevertheless, the kinetic evidence obtained in the present study could also point to a direct electron transfer to centre II. This was supported by the similarity of the rate constant values found for the $\mathrm{SOR}_{\mathrm{Fe}(\mathrm{III}) \mathrm{Fe}(\mathrm{III})}$ form at $500 \mathrm{~nm}$ (oxidation of rubredoxin) and $650 \mathrm{~nm}$ (reduction of centre II of SOR), which were themselves similar to the calculated values for the $\mathrm{Zn} / \mathrm{Fe}-\mathrm{SOR}$ form (where centre $\mathrm{I}$ is not redox active).

An explanation for this apparent inconsistency can be found in the electrochemical data that strongly suggests the existence of two different pathways for the electron-transfer processes in $2 \mathrm{Fe}$ SOR. In such a case, one exclusively due to the direct electron transfer between the electrode and the protein, and a second one that can only be explained by an intramolecular electron transfer from centre I to centre II (which, as expected, is missing in the $\mathrm{Zn} / \mathrm{Fe}-\mathrm{SOR}$ form). Also, the electrochemical behaviour points to probable conformational changes in the protein, possibly triggered by redox changes in centre II.

This type of long-range [22 $\AA(1 \AA=0.1 \mathrm{~nm})]$ intramolecular electron transfer, coupled to conformational change, is not unique in Nature, being found in other examples such as $\mathrm{CcO}$ (cytochrome $c$ oxidase) $[42,43]$.

One should also consider the fact that in the superoxidemediated electron-transfer assay, values of $k^{\prime}$ for forms with centre II reduced $\left[\mathrm{SOR}_{\mathrm{Fe}(\mathrm{III})-\mathrm{Fe}(\mathrm{II})}, \mathrm{SOR}_{\mathrm{Fe} \text { (II)-Fe(II) }}\right.$ and $\left.\mathrm{SOR}_{\mathrm{Zn} \text { (II)-Fe(II) }}\right]$ are of the same magnitude and significantly higher than $k^{\prime}$ values estimated for forms with an oxidized centre II [SOR $\mathrm{Se}_{\mathrm{Fe}(\mathrm{III})-\mathrm{Fe}(\mathrm{III})}$ and $\left.\mathrm{SOR}_{\mathrm{Zn}(\mathrm{II})-\mathrm{Fe}(\mathrm{III})}\right]$. So, an enzyme with a reduced centre II will have higher turnover rates, also being more able to stay in that state due to the possibility of an intramolecular electron transfer and to the enhanced rate of reduction of centre I. It is then possible to hypothesize that, when active, intracellular concentrations of $\mathrm{SOR}_{\mathrm{Fe}(\mathrm{III})-\mathrm{Fe}(\mathrm{III})}$ forms are negligible and that the enzyme is kept either in a 'ready' $\mathrm{SOR}_{\mathrm{Fe}(\mathrm{III})-\mathrm{Fe}(\mathrm{II})}$ state or in a fully reduced form, $\mathrm{SOR}_{\mathrm{Fe}(\mathrm{II}) \mathrm{Fe}(\mathrm{II})}$. Therefore the existence of centre I can be seen as a structural advantage to the enzyme, enabling it to be more efficient in the metabolic pathway and helping the cell to keep a pool of 'ready' enzyme for catalysis [19].

The enzymes in question were isolated from microaerophilic Desulfovibrio species where an effective defence mechanism against ROS is essential for survival, and as such one would expect the enzyme to be adapted to the highest possible turnover rates.

\section{AUTHOR CONTRIBUTION}

Filipe Folgosa, Cristina Cordas and Joana Santos conducted most of the experiments, analysed the data and prepared the paper. Alice Pereira, José Moura, Pedro Tavares and Isabel Moura supervised, reviewed and edited the paper prior to submission.

\section{FUNDING}

This work was supported by Fundação para a Ciência e Tecnologia (FCT) [project number POCI/QUI/57475/2004], a Ph.D. grant to F.F. [grant number SFRH/BD/18905/2004] and a Ph.D. grant to C.C. [grant number SFRH/BD/2917/2000].

\section{REFERENCES}

1 Elstner, E. F. (1982) Oxygen activation and oxygen-toxicity. Annu. Rev. Plant Physiol. Plant Mol. Biol. 33, 73-96

2 Bollinger, Jr, J. M. and Krebs, C. (2006) Stalking intermediates in oxygen activation by iron enzymes: motivation and method. J. Inorg. Biochem. 100, 586-605

3 Costas, M., Mehn, M. P., Jensen, M. P. and Que, Jr, L. (2004) Dioxygen activation at mononuclear nonheme iron active sites: enzymes, models, and intermediates. Chem. Rev. 104, 939-986

4 Korendovych, I. V., Kryatov, S. V. and Rybak-Akimova, E. V. (2007) Dioxygen activation at non-heme iron: insights from rapid kinetic studies. Acc. Chem. Res. 40, 510-521

5 Decker, A. and Solomon, E. I. (2005) Dioxygen activation by copper, heme and non-heme iron enzymes: comparison of electronic structures and reactivities. Curr. Opin. Chem. Biol. 9, 152-163

6 Zhang, R. G., Kim, Y., Skarina, T., Beasley, S., Laskowski, R., Arrowsmith, C., Edwards, A. Joachimiak, A. and Savchenko, A. (2002) Crystal structure of Thermotoga maritima 0065 a member of the IcIR transcriptional factor family. J. Biol. Chem. 277, 19183-19190

7 Tavares, P., Ravi, N., Moura, J. J., LeGall, J., Huang, Y. H., Crouse, B. R., Johnson, M. K., Huynh, B. H. and Moura, I. (1994) Spectroscopic properties of desulfoferrodoxin from Desulfovibrio desulfuricans (ATCC 27774). J. Biol. Chem. 269, 10504-10510 
8 Moura, I., Tavares, P. and Ravi, N. (1994) Characterization of three proteins containing multiple iron sites: rubrerythrin, desulfoferrodoxin, and a protein containing a six-iron cluster. Methods Enzymol. 243, 216-240

9 Chen, L., Sharma, P., Le Gall, J., Mariano, A. M., Teixeira, M. and Xavier, A. V. (1994) A blue non-heme iron protein from Desulfovibrio gigas. Eur. J. Biochem. 226 613-618

10 Moura, I., Tavares, P., Moura, J. J., Ravi, N., Huynh, B. H., Liu, M. Y. and LeGall, J. (1990) Purification and characterization of desulfoferrodoxin. A novel protein from Desulfovibrio desulfuricans (ATCC 27774) and from Desulfovibrio vulgaris (strain Hildenborough) that contains a distorted rubredoxin center and a mononuclear ferrous center. J. Biol. Chem. $\mathbf{2 6 5}, 21596-21602$

11 Jenney, F. E., Verhagen, M. and Adams, M. W. W. (1999) Neelaredoxin from Pyrococcus furiosus is a novel type of superoxide dismutase. J. Inorg. Biochem. 74, 181-181

12 Lombard, M., Touati, D., Fontecave, M. and Niviere, V. (2000) Superoxide reductase as a unique defense system against superoxide stress in the microaerophile Treponema pallidum. J. Biol. Chem. 275, 27021-27026

13 Abreu, I. A., Saraiva, L. M., Carita, J., Huber, H., Stetter, K. O., Cabelli, D. and Teixeira, M. (2000) Oxygen detoxification in the strict anaerobic archaeon Archaeoglobus fulgidus: superoxide scavenging by neelaredoxin. Mol. Microbiol. 38, 322-334

14 Rodrigues, J. V., Saraiva, L. M., Abreu, I. A., Teixeira, M. and Cabelli, D. E. (2007) Superoxide reduction by Archaeoglobus fulgidus desulfoferrodoxin: comparison with neelaredoxin. J. Biol. Inorg. Chem. 12, 248-256

15 Yeh, A. P., Hu, Y., Jenney, Jr, F. E., Adams, M. W. and Rees, D. C. (2000) Structures of the superoxide reductase from Pyrococcus furiosus in the oxidized and reduced states. Biochemistry 39, 2499-2508

16 Jovanovic, T., Ascenso, C., Hazlett, K. R., Sikkink, R., Krebs, C., Litwiller, R., Benson, L. M., Moura, I., Moura, J. J., Radolf, J. D. et al. (2000) Neelaredoxin, an iron-binding protein from the syphilis spirochete, Treponema pallidum, is a superoxide reductase. J. Biol. Chem. 275, 28439-28448

17 Jenney, Jr, F. E., Verhagen, M. F., Cui, X. and Adams, M. W. (1999) Anaerobic microbes: oxygen detoxification without superoxide dismutase. Science 286, 306-309

18 McCord, J. M. and Fridovich, I. (1988) Superoxide dismutase: the first twenty years (1968-1988). Free Radical Biol. Med. 5, 363-369

19 Pereira, A. S., Tavares, P., Folgosa, F., Almeida, R. M., Moura, I. and Moura, J. J. G. (2007) Superoxide reductases. Eur. J. Inorg. Chem. 18, 2569-2581

20 Czaja, C., Litwiller, R., Tomlinson, A. J., Naylor, S., Tavares, P., LeGall, J., Moura, J. J., Moura, I. and Rusnak, F. (1995) Expression of Desulfovibrio gigas desulforedoxin in Escherichia coli. Purification and characterization of mixed metal isoforms. J. Biol. Chem. 270, 20273-20277

21 Archer, M., Huber, R., Tavares, P., Moura, I., Moura, J. J., Carrondo, M. A., Sieker, L. C., LeGall, J. and Romao, M. J. (1995) Crystal structure of desulforedoxin from Desulfovibrio gigas determined at $1.8 \AA$ A resolution: a novel non-heme iron protein structure. J. Mol. Biol. 251, 690-702

22 Devreese, B., Tavares, P., Lampreia, J., Van Damme, N., Le Gall, J., Moura, J. J., Van Beeumen, J. and Moura, I. (1996) Primary structure of desulfoferrodoxin from Desulfovibrio desulfuricans ATCC 27774, a new class of non-heme iron proteins. FEBS Lett. 385, 138-142

23 Clay, M. D., Jenney, Jr, F. E., Hagedoorn, P. L., George, G. N., Adams, M. W. and Johnson, M. K. (2002) Spectroscopic studies of Pyrococcus furiosus superoxide reductase: implications for active-site structures and the catalytic mechanism. J. Am. Chem. Soc. 124, 788-805

Received 10 May 2011/14 June 2011; accepted 17 June 2011

Published as BJ Immediate Publication 17 June 2011, doi:10.1042/BJ20110836
24 Auchere, F., Sikkink, R., Cordas, C., Raleiras, P., Tavares, P., Moura, I. and Moura, J. J. (2004) Overexpression and purification of Treponema pallidum rubredoxin; kinetic evidence for a superoxide-mediated electron transfer with the superoxide reductase neelaredoxin. J. Biol. Inorg. Chem. 9, 839-849

25 Mathe, C., Niviere, V. and Mattioli, T. A. (2005) $\mathrm{Fe}^{3+}$-hydroxide ligation in the superoxide reductase from Desulfoarculus baarsii is associated with $\mathrm{pH}$ dependent spectral changes. J. Am. Chem. Soc. 127, 16436-16441

26 Rodrigues, J. V., Abreu, I. A., Saraiva, L. M. and Teixeira, M. (2005) Rubredoxin acts as an electron donor for neelaredoxin in Archaeoglobus fulgidus. Biochem. Biophys. Res. Commun. 329, 1300-1305

27 Emerson, J. P., Coulter, E. D., Phillips, R. S. and Kurtz, Jr, D. M. (2003) Kinetics of the superoxide reductase catalytic cycle. J. Biol. Chem. 278, 39662-39668

28 Emerson, J. P., Coulter, E. D., Cabelli, D. E., Phillips, R. S. and Kurtz, Jr, D. M. (2002) Kinetics and mechanism of superoxide reduction by two-iron superoxide reductase from Desulfovibrio vulgaris. Biochemistry 41, 4348-4357

29 Ascenso, C., Rusnak, F., Cabrito, I., Lima, M. J., Naylor, S., Moura, I. and Moura, J. J. (2000) Desulfoferrodoxin: a modular protein. J. Biol. Inorg. Chem. 5, 720-729

30 Emerson, J. P., Cabelli, D. E. and Kurtz, Jr, D. M. (2003) An engineered two-iron superoxide reductase lacking the [Fe(SCys)4] site retains its catalytic properties in vitro and in vivo. Proc. Natl. Acad. Sci. U.S.A. 100, 3802-3807

31 Auchere, F., Pauleta, S. R., Tavares, P., Moura, I. and Moura, J. J. (2006) Kinetics studies of the superoxide-mediated electron transfer reactions between rubredoxin-type proteins and superoxide reductases. J. Biol. Inorg. Chem. 11, 433-444

32 Lowry, O. H., Rosebrough, N. J., Farr, A. L. and Randall, R. J. (1951) Protein measurement with the Folin phenol reagent. J. Biol. Chem. 193, 265-275

33 Wisitruangsakul, N., Zebger, I., Ly, K. H., Murgida, D. H., Ekgasit, S. and Hildebrandt, P. (2008) Redox-linked protein dynamics of cytochrome c probed by time-resolved surface enhanced absorption spectroscopy. Phys. Chem. Chem. Phys. 10, 5276-5286

34 Verhagen, M. F., Voorhorst, W. G., Kolkman, J. A., Wolbert, R. B. and Hagen, W. R. (1993) On the two iron centers of desulfoferrodoxin. FEBS Lett. 336, 13-18

35 Winter, M. J. (1994) d-Block Chemistry, Oxford University Press, Oxford

36 Correia dos Santos, M. M., Paes de Sousa, P. M., Simões Gonçalves, M. L., Ascenso, C., Moura, I. and Moura, J. J. G. (2001) Electrochemical studies of rubredoxin from Desulfovibrio vulgaris at modified electrodes. J. Electroanal. Chem. 501, 173-179

37 Léger, C. J., Jones, A. K., Albracht, S. P. J. and Armstrong, F. A. (2002) Effect of a dispersion of interfacial electron transfer rates on steady state catalytic electron transport in [NiFe]-hydrogenase and other enzymes. J. Phys. Chem. B. 106, 13058-13063

38 Moore, G. R., Pettigrew, G. W. and Rogers, N. K. (1986) Factors influencing redox potentials of electron-transfer proteins. Proc. Natl. Acad. Sci. U.S.A. 83, 4998-4999

39 Chiku, M., Nakamura, J., Fujishima, A. and Einaga, Y. (2008) Conformational change detection in nonmetal proteins by direct electrochemical oxidation using diamond electrodes. Anal. Chem. 80, 5783-5787

40 Rodrigues, J. V., Abreu, I. A., Cabelli, D. and Teixeira, M. (2006) Superoxide reduction mechanism of Archaeoglobus fulgidus one-iron superoxide reductase. Biochemistry $\mathbf{4 5}$ 9266-9278

41 Coulter, E. D. and Kurtz, Jr, D. M. (2001) A role for rubredoxin in oxidative stress protection in Desulfovibrio vulgaris: catalytic electron transfer to rubrerythrin and two-iron superoxide reductase. Arch. Biochem. Biophys. 394, 76-86

42 Poulos, T. L., Li, H. and Raman, C. S. (1999) Heme-mediated oxygen activation in biology: cytochrome c oxidase and nitric oxide synthase. Curr. Opin. Chem. Biol. 3, 131-137

43 Page, C. C., Moser, C. C., Chen, X. and Dutton, P. L. (1999) Natural engineering principles of electron tunnelling in biological oxidation-reduction. Nature $\mathbf{4 0 2}, 47-52$ 


\title{
SUPPLEMENTARY ONLINE DATA \\ New spectroscopic and electrochemical insights on a class I superoxide reductase: evidence for an intramolecular electron-transfer pathway
}

\author{
Filipe FOLGOSA, Cristina M. CORDAS, Joana A. SANTOS ${ }^{1}$, Alice S. PEREIRA, José J. G. MOURA, Pedro TAVARES ${ }^{2}$ and \\ Isabel MOURA2 \\ REQUIMTE/CQFB, Departamento de Química, Faculdade de Ciências e Tecnologia, Universidade Nova de Lisboa, 2829-516 Caparica, Portugal
}

\section{EXPERIMENTAL}

\section{Overexpression and purification of recombinant $D$. vulgaris Hildenborough rubredoxin}

D. vulgaris Hildenborough rubredoxin was overexpressed and purified to homogeneity following a protocol modified from one published previously $[1,2]$. In the present study, cultures in LB medium containing ampicillin $(0.1 \mathrm{mg} / \mathrm{ml})$ were grown until $A_{600 \mathrm{~nm}}=0.8$, at which point IPTG and $\mathrm{FeCl}_{2}$ were added to a final concentration of 1 and $0.1 \mathrm{mM}$ respectively. The culture was allowed to grow for approximately $14 \mathrm{~h}$ at room temperature (between 293.15 and $298.15 \mathrm{~K}$ ) at $230 \mathrm{rev} . / \mathrm{min}$. After growth, cells were harvested by centrifugation at $7000 \mathrm{~g}$ for $10 \mathrm{~min}$ at $277.15 \mathrm{~K}$. The supernatant was discarded and the cells were suspended in $50 \mathrm{mM}$ Tris/ $\mathrm{HCl}(\mathrm{pH}$ 7.6) buffer. A combination of freeze-thaw cycles and an homogenizer [10000 psi (1 psi = $6.9 \mathrm{kPa})$ ] apparatus were used for cell disruption. Cell disruption was followed by ultracentrifugation at $42000 \mathrm{rev} . / \mathrm{min}$ at $4^{\circ}$ for $90 \mathrm{~min}$, to remove unbroken cells and cell debris. The fraction was then loaded into a XK26/40 column $(2.6 \mathrm{~cm} \times 40 \mathrm{~cm}$, GE Healthcare) packed with a DEAE-Sepharose $\mathrm{FF}^{\circledR}$ medium (GE Healthcare), previously equilibrated with $50 \mathrm{mM}$ Tris/ $\mathrm{HCl}$ ( $\mathrm{pH}$ 7.6) buffer. The protein was eluted from the column with a linear gradient of 50-500 mM Tris/ $\mathrm{HCl}(\mathrm{pH} 7.6)$. Fractions were collected and assayed for rubredoxin by measuring the absorbance ratio between 280 and $490 \mathrm{~nm}$. The best fractions in terms of purity (lowest ratio) were combined and concentrated using an ultrafiltration system Diaflo ${ }^{\circledR}$ equipped with a YM3 membrane, before the next chromatographic step. The protein was loaded on to a column $(2.6 \mathrm{~cm} \times 100 \mathrm{~cm})$ filled with a gel-filtration medium (Superdex 75, GE Healthcare) equilibrated with $300 \mathrm{mM} \mathrm{Tris} / \mathrm{HCl}$ ( $\mathrm{pH}$ 7.6), and eluted with the same buffer. The most pure fractions $\left(A_{280} / A_{490}=2.4\right)$ were pooled and concentrated using a Diaflo ${ }^{\circledR}$ equipped with a YM3 membrane.

\section{Overexpression and purification of recombinant $D$. gigas desulforedoxin}

D. gigas desulforedoxin was overexpressed and purified to homogeneity following a protocol modified from one published previously [3]. In the present study, LB medium was also supplemented with $\mathrm{FeCl}_{2}$ at the time of induction to a final concentration of $0.1 \mathrm{mM}$. The culture was allowed to grow for approximately $14 \mathrm{~h}$ at room temperature (between 293.15 and $298.15 \mathrm{~K})$ at $230 \mathrm{rev} . / \mathrm{min}$. The next purification steps were similar to the ones described above for $D$. vulgaris Hildenborough rubredoxin. Following the purification steps, the most pure fractions $\left(A_{278} / A_{507}=1.36\right)$ were pooled and concentrated using a Diaflo $^{\circledR}$ equipped with a YM3 membrane.

\section{Spectroscopic and kinetic characterization}

Characterization consisted of the reduction of superoxide anion by catalytic amounts of SOR. Reduced rubredoxin is used as an electron donor while its oxidation is monitored to calculate the reaction rate. This way, a measurement of the superoxide reductase activity of each form of SOR enzyme can be calculated. The reagents were always added in the same order and within the same time scale in order to keep the same experimental conditions. Rubredoxin was added to the assay in the oxidized form and then reduced with equimolar quantities of sodium dithionite. The amounts of xanthine $(1.5 \mathrm{mM})$ and xanthine oxidase $(0.058$ units $/ \mathrm{ml})$ were such as to ensure a constant flux of superoxide during the reaction (approximately $14 \mu \mathrm{M} \cdot \mathrm{min}^{-1}$ ). The addition of catalase ( $150 \mathrm{units} / \mathrm{ml})$ was necessary to remove the hydrogen peroxide formed by spontaneous superoxide dismutation, xanthine/xanthine oxidase system (also a reaction product) and superoxide reduction (with SOR), in order to prevent any inhibition by product [4-6].

\section{Electrochemical measurements}

Electrochemical measurements were performed at different temperatures using a one compartment electrochemical thermostat jacket cell. Cyclic voltammetry was performed at different scan rates (from 1 to $100 \mathrm{mV} / \mathrm{s}$ ). SW voltammograms of the $2 \mathrm{Fe}-\mathrm{SOR}$ centre I, with the potential scanned on the cathodic direction, allowed estimation of the redox formal potential as $-25 \mathrm{mV}$ compared with NHE, as can be observed in Figure S1. Experimental parameters were: room temperature, gold working electrode, step potential of $5 \mathrm{mV}$, amplitude of $20 \mathrm{mV}$, frequency of $8 \mathrm{~Hz}$ and $v=40 \mathrm{mV} / \mathrm{s}$. Before each scan, in both the cathodic and anodic direction, the protein was subjected to a small $2 \mathrm{~s}$ delay at the initial scan potentials, corresponding to an electrolysis time at that potential.

\footnotetext{
1 Present address: Instituto de Biologia Molecular e Celular, Rua do Campo Alegre, 823, 4150-180 Porto, Portugal

2 Correspondence may be addressed to either of these authors (email pedro.tavares@dq.fct.unl.pt or isa@dq.fct.unl.pt).
} 


\section{E IV vs NHE}

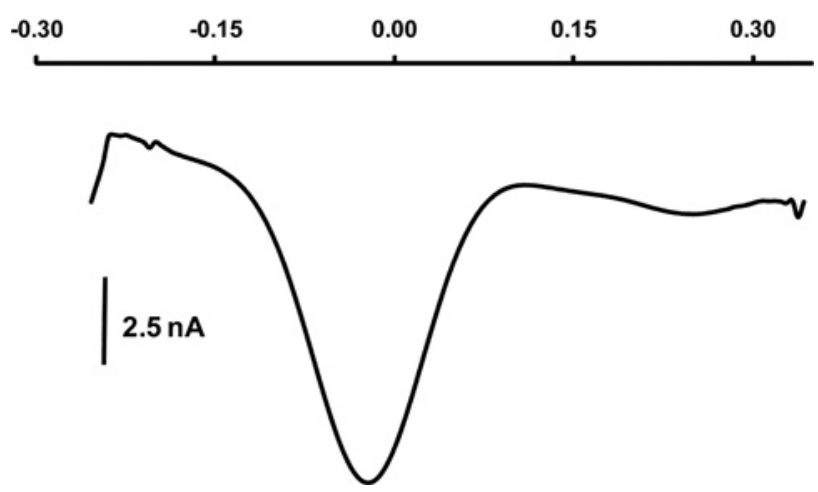

\section{Figure S1 SW voltammogram of 2Fe-SOR scanned in the cathodic direction}

SW voltammetry plot of $2 \mathrm{Fe}-\mathrm{SOR}$ scanned in the cathodic direction. Experimental parameters: room temperature, gold working electrode, step potential of $5 \mathrm{mV}$, amplitude of $20 \mathrm{mV}$, frequency $8 \mathrm{~Hz}$ and $v=40 \mathrm{mV} / \mathrm{s}$.

\section{REFERENCES}

1 Auchere, F., Pauleta, S. R., Tavares, P., Moura, I. and Moura, J. J. (2006) Kinetics studies of the superoxide-mediated electron transfer reactions between rubredoxin-type proteins and superoxide reductases. J. Biol. Inorg. Chem. 11, 433-444

2 Auchere, F., Sikkink, R., Cordas, C., Raleiras, P., Tavares, P., Moura, I. and Moura, J. J. (2004) Overexpression and purification of Treponema pallidum rubredoxin; kinetic evidence for a superoxide-mediated electron transfer with the superoxide reductase neelaredoxin. J. Biol. Inorg. Chem. 9, 839-849

3 Czaja, C., Litwiller, R., Tomlinson, A. J., Naylor, S., Tavares, P., LeGall, J., Moura, J. J., Moura, I. and Rusnak, F. (1995) Expression of Desulfovibrio gigas desulforedoxin in Escherichia coli. Purification and characterization of mixed metal isoforms. J. Biol. Chem. 270, 20273-20277

4 Link, E. M. and Riley, P. A. (1988) Role of hydrogen peroxide in the cytotoxicity of the xanthine/xanthine oxidase system. Biochem. J. 249, 391-399

5 Kellogg, III, E. W. and Fridovich, I. (1975) Superoxide, hydrogen peroxide, and singlet oxygen in lipid peroxidation by a xanthine oxidase system. J. Biol. Chem. 250, 8812-8817

6 Fridovich, I. (1975) Superoxide dismutases. Annu. Rev. Biochem. 44, 147-159

Received 10 May 2011/14 June 2011; accepted 17 June 2011

Published as BJ Immediate Publication 17 June 2011, doi:10.1042/BJ20110836 